\title{
Procedural conflict of appointment and production of Forensic building-technical expertise (FBTE) and methodological approaches for their resolution
}

\author{
Svetlana Kolobova ${ }^{1, *}$ \\ ${ }^{1}$ Moscow State University of Civil Engineering, Yaroslavskoe shosse, 26, Moscow, 129337, Russia
}

\begin{abstract}
This paper analyzes the procedural conflicts arising from the appointment and manufacture of forensic building-technical expertise and methodical recommendations for their resolution. Inconsistencies in some provisions of current legislation governinjudicial activities: the concept of forensic expertise, the legal status of forensic expert, the name of the types of forensic expertise, the legal classification of judicial expertise can lead to the wrong judicial conclusions and judicial errors. The methodological approaches for legislative consolidation of the definition of activities; changes in the civil procedural code, arbitration procedural code, code on administrative offences, Federal law on state expert activity related to the unification of forensic-expert terminology and inclusion in the legal framework of new concepts concerning expert activities. It is proposed to amend the administrative procedure law regarding the timing of execution of forensic building-technical expertise and revision sanctions in case of untimely performance of building-technical expertise.
\end{abstract}

\section{Introduction}

A special role in the market system countries occupy the real estate, including construction sites, which are involved in the economic mechanism and are the objects of economic transactions. Currently, the functioning of the market of real estate involved in all spheres of economic and social life of Russian society [1]. According to Rosstat, the share of construction in GDP of Russia in the period of 2003-2014 average remains at $5.5 \%$ [2]. In 2015-2016 there was a decrease in GDP growth rate[3].

"Smart city", which is more than 20 years, discussed in the scientific community, provides a qualitatively new level of urban policy, which consists in the introduction of innovations in the urban environment [4]. But before you start construction, all projects undergo a mandatory examination. It should be noted that estimates of the Committee for pricing policy in construction and state examination of projects in 2016 in comparison with the previous year was a positive trend in the number of issued certificates on construction sites financed at the expense of budgetary funds of Moscow. The Chairman of Moskomekspertiza Valery Leonov reported that from January 2016 issued 3148

* Corresponding author: KolobovaSV@mgsu.ru 
conclusions: this is almost 2.5 thousand positive opinions more than were issued last year. For all of last year there were only 2110 conclusions: both positive and negative, which means the coordinated work of experts and the responsible attitude of customers [5].

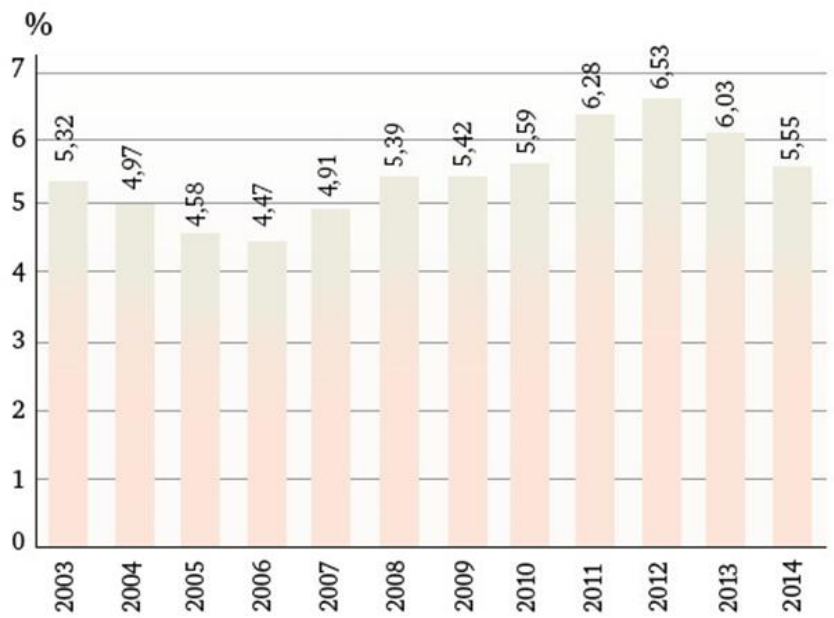

Fig. 1.The share of construction in GDP of Russia in 2003-2014 gg

Managers and architects construction companies and analyse the reasons for slow adoption of the concept of "Smart city" in the Russian urban environment. "Smart grid deployment unfolds within a diverse array of multi-institutional arrangements that may be too fragmented and decentralized to allow for the kind of large-scale and coordinated investments needed to properly deploy the smart grid" [6] The salience and complexity of building, regulating, and governing the smart grid: Lessons from a statewide public-private partnership Original Research Article Energy Policy, Volume 74, November 2014, Pages 243-252 Christopher Koliba, Mercy DeMenno, Nancy Brune, Asim Zia].

If 20 years ago, the Russian city was technically not ready for anything like that now smart-tools - related software solutions and equipment became available, however, the introduction of smart concepts on the scale of neighborhoods, districts, city transportation or utilities almost inhibited [7].Transportation projects contain many tradeoffs between environmental, social, and economic benefits and costs that affect different groups of stakeholders, each with different priorities and values [8].

The questions of influence of the use of expert knowledge for the implementation of development plans of land use and transport planning in three Scandinavian cities was devoted to art Aud Tennøy, Lisa Hansson, Enza Lissandrello, Petter Næss[9] .

The involvement of a large number of parties involved in the civil construction industry requires the legal regulation of their economic activities. Unfortunately, in the course of production activity in the construction industry are made offenses and crimes by the subjects of this activity. Performance targets to increase the scale and pace of construction [10] and the desire to maximize profits in the construction industry for many years has both positive and negative aspect associated with the permanent violation of Federal law and safety regulations, fire safety, not compliance with building rules and regulations and other technical regulations, which leads to tragic consequences associated with the loss of life or causing them grievous bodily harm, premature destruction of construction objects [11]. Security and the required quality of performed engineering survey, design, construction, commissioning and other works in construction is currently beyond the scope of intraindustry problems and becomes one of the most important national objectives. In its decision the need to consider scientific, technical, technological, organizational, 
managerial, financial-economic aspects and issues of legal support of the entire construction cycle.Often controversial issues, the participants of the construction market to decide in a judicial order [12].Forensic building-technical expertise (FBTE) remains very popular among different kind of expertise. The court considered the claims of multimilliondollar construction companies and mostly from expert opinion depends on the court decision. In civil and commercial courts the parties in the case, as a rule, turn yourself with the petition for appointment of judicial examination and the right to offer expert institution and (or) non-governmental experts, and to propose questions to be answered by the expert.In many situations we need to obtain one, common decision (which can be understood as a consistent state of knowledge) out of opinions collected from many experts or any other external sources [13].

The final decision about the definition of expert and expert organizations, as well as a list of issues that should be examined, determined by the court. Expert evidence is important evidence that helps the court to objectively assess the behavior of the subject from a legal point of view, and properly resolve the case on the merit.

The problem of how to integrate expert knowledge with democratic politics has preoccupied scholars for more than a century but has become highly salient for Science and Technology Studies (STS) scholarship in recent decades. Science and Technology Studies: Experts and Expertise [14]

Significant evidence has accumulated describing the importance of expertise. As this knowledge is extended, it is critical to understand when expertise matters and how [15].

Judicial ethics and the relationship the court has devoted its head Ronald Miller, Brent E. Turvey. This chapter discusses judicial integrity, conflicts of interest, knowledge of the law, time allotment and caseload, improper influence over the jury, ethical issues with experts, improper judicial behavior, judicial alertness during trial, reporting attorney misconduct, and post-conviction issues[16].

\section{Discussion and result ssection}

Legal regulation of appointment and manufacture of forensic building-technical expertise (FBTE) provides for a specific procedural form, according to norms of the arbitration procedure code (APC), the civil procedure code (CPC), the criminal procedure code $(\mathrm{CrPC})$, code of administrative offences (CAO), code of administrative procedure (CAS) of the Russian Federation and organizational form, in accordance with applicable departmental regulations: GOST and SNiP, different instructions associated with the construction and operation of facilities.

In civil and commercial courts the parties in the case, usually their own appeal with the petition for appointment of judicial examination and the right to offer expert institution and (or) non-governmental experts, and to propose questions to be answered by the expert. The final list of issues to be studied, defines the civil and arbitration court.

The main point in filing a claim is the right choice of a competent expert (group of experts) and a clear formulation of the issues that affect the absoluteness of the results of the expert and as a consequence - justice resolve the dispute on the merits. This is very important, because practical issues are often "lose" at this stage. The place of expertise in modern systems of government continues to be of concern to critical social scientists [17].

Procedural law provides that if the expert during the examination will establish circumstances that are important for business and about which he had questions, he has the right to include conclusions about these circumstances in its opinion. Expert evidence is important evidence, help the court to correctly assess the behavior of the subject from a legal point of view, and properly resolve the case on the merits. 
The quality of a formal decision is influenced by the level of expertise of the decision makers [18].

Established a certain experience of the expert in our country allow us to point to some conflicts in procedural law. Doctor of juridical Sciences, Professor T. F. Moiseeva, Deputy head of Department of criminal procedural law, criminalistics and forensic expertise them. N. In. Radutny Russian state University of justice at the International conference in 2015 in the report "Issues of procedural regulation of judicial-expert activity in the code of criminal procedure, code of civil procedure, code of administrative offencesof the Russian Federation and of the Russian Federation" rightly pointed out the inconsistencies in some provisions of current legislation governingthe forensic activities, for example, differences in the formulation of such guidelines as the concept of judicial expertise, the legal status of a forensic expert, the legal classification of forensic examinations, stressed the need for unification of legal regulation of forensic activities in the Russian Federation [19].

As follows from the Decision of the Plenum of the Supreme Arbitration Court of the Russian Federation Nr. 66 of 20 December 2006 "On some issues of practice of application by arbitration courts of the legislation on examination", the examination can be carried out in the state judicial-expert establishment or a non-state expert organizations, or construction expertise can be engaged persons with special knowledge. And set personally in the arbitration court, both state and non-state experts. Expert opinion non-expert may not be challenged only because of the fact that the relevant expertise could be delegated to the state forensic institution. This issue was again raised at the international scientific-practical conferences. So, at the II International scientific-practical conference "Forensic examination: Russian and international experience" held on May 21-22, Volgograd, conference Director Uralo-Povolzhskaya Association of forensic experts F. G. Aminev, in his report, argues that we need legislation to give a clear definition of forensic activities, which, in the framework of a democratic state and civil society is a scientific and methodological activities of state and non-state forensic expert institutions and other experts from among competent persons who are in the manufacture of judicial examination on behalf of the authorized person or body that appointed it. This is especially important because almost $80 \%$ of examinations in civil proceedings is performed non-state forensic organizations [20]. At the V International scientific-practical conference "Theory and practice of forensic examination in modern conditions" held in Moscow on 22-23 January 2015, the conference Goloshchapova T. I. Gusakova, Y. A. Krasovskaya E. A. Voropaeva O. V. noted the importance of the unification of production of judicial examinations, stressing that the activities of state and non-state experts should be carried out according to uniform rules in the absence of the state monopoly in this sphere. At the forefront the authors of the performances put requirements the harmonization of the competence of experts (regardless of their status), in order to comply with guaranteed by the Constitution of the Russian Federation the rights of citizens to receive qualified legal assistance [19].

In accordance with article 87 of the CPC may be conducted additional re-examination in cases of insufficient clarity or incompleteness of the expert's report in connection with the arisen doubts in correctness or validity informed of this conclusion, the presence of contradictions in conclusions of several experts. The conflict lies in the fact that, unlike agriculture, in article 87 of the CPC there is no such basis, the appointment of additional and repeated expert examination as the emergence of new issues for this office and it is almost equal to the incompleteness of the expert's report. The question is, for whatever reason, require additional or re-examination: due to the shortcomings of the expert, and this is a negative subjective factor, or the objective reason for the appearance in court of the new circumstances, documents, and, consequently, new questions. 
Thus, if the court does not doubt the competence of the expert and the correctness of his conclusions, and only needs to be clarified and expanded answers, additional examination charge the same SAU or expert for revision.

In this case, a more thorough preparation for conducting the research and competence of the expert in constructing a logical chain of all studies and summarizing would be able to eliminate the negative subjective factor, and then there is not need for additional studies, and therefore additional labor costs and delays in the judicial process at the time.

Can be difficult court (judge) summarizing the results of the expert opinions in conducting Commission and comprehensive examinations, if expert opinions differ.

In fact, the examination Commission appointed to study complex, large, multifunctional properties of a complex of buildings, structures, buildings, land use, large area and varied in structure. Members of the Commission - experts conduct each fully their research together or separately, according to a collective decision. If the opinions of experts on the surveys are consistent, then they sign a single opinion or declare the impossibility of giving an opinion. In this case, the decision rests with the court. Then from the personal subjective qualities of a judge will depend on the outcome of the case.

The ambiguity of a Commission examination may occur in case of impossibility of giving a unified conclusion of experts, where each expert (expert), gives his separate opinion that does not coincide with the opinion of other experts of the Commission. In this confusing case, the court may not make a final decision and the process will be delayed as the court (judge) will require additional time for decision-making and, most likely, on the appointment of re-examination.

When you want to get answers to questions in different directions and it is necessary to conduct research in different fields of knowledge appoint a comprehensive examination [21]. The principle of organizational work comprehensive examination is the same as Commission. According to the results of a comprehensive examination each examiner formulates their own conclusions. In this case, for the court has the right of last resort and the final output according to the experts of different specialties.

Forensic expertise in civil proceedings shall be appointed upon the request of any of the parties involved in case of dispute and failure to reach settlement of the conflict in the pretrial order. Usually conflicts arise between the customer and the contractor for the following reasons: by reason of defects in the performed construction works or the cause (part 5, article 720 of the civil code), by reason of accidental destruction or accidental damage of the construction object (arts. 741,742 GK), if the inferior quality of the performed works, the occurrence of building defects and their possible consequences (arts. $710,713,715,716,721,723,724,737,748,753,754,757,761,762$ GK), not of observance of requirements of legislation on environmental protection and safety construction works (article 751 civil code). The court engages the expert-Builder for the recognition of ownership of unauthorized construction, if an administrative order this was not done (articles 222, 263 GK).

Forensic expertise in civil proceedings shall be appointed upon the request of any of the parties involved in case of dispute and failure to reach settlement of the conflict in the pretrial order. Great practical significance acquired SSTA on disputes about title to real estate and housing disputes related to division of property, apportionment of share of property which in equity and joint property (articles 252, 254, 258 of the civil code). Procedural issues often arise when persons not interested in the examination, create barriers to accessing expert in residential areas and on private land. The expert, based on the articles of the law: part 2 of article 19 and paragraph 5 of article 10 of the Federal law on state forensic activities (GSED) to provide expert body (person) that appointed the expert examination unimpeded access to object and possibility of its research petitioning for the organization of carrying out examination on the spot. Despite this, courts have sometimes 
refused to the experts in this, referring to article 25 of the Constitution on the inviolability of the home. In this case, the supremacy of the Constitution is obvious, although contradictory regarding the law on GSED, which leads to a deadlock. Thus, the court does not always provide the possibility of inspection of the object of study. Then, the expert is obliged to inform about the impossibility of giving an opinion. To prevent such situations, the court should take an active civil position in execution of article 19 of the Federal law on GSAD. Constitutional law in this case will be respected, if not violated the rights of third parties.

Examination shall be for the following reasons:

- for the initiation of a civil case before trial by the court (part 2 of article 96 code of civil procedure, Part 1 of article 187 of the CCP). At the time of the examination, the proceedings shall be suspended (article 216 of the CPC);

- to collect evidence (article 64CPC ). The participants in the process, having reason to fear that the presentation of these proofs will be subsequently impossible or difficult, may ask the court about providing this evidence. The examination may also be assigned by a court on the territory of activities of which is to be made procedures to collect evidence;

- at trial, and in preparation for the case on trial. In accordance with article 152 of the code of civil procedure, the parties in the preliminary hearing have the right to present evidence, to present arguments, to declare petitions, including about appointment of examination for establishment of evidence in the case. Is assigned to any of the examinations primary, repeated, additional, and the proceedings may be suspended (article 216 of the $\mathrm{CPC}$ ), since many studies require more time for inspection, documentation, calculations, etc.;

- the order of the court (article 62 of the CCP). The court hearing the case, if necessary, obtaining evidence located in another city or district, requests the court to perform certain procedural actions. This occurs if a building is located geographically remotely, or involves experts any specialization, operating in another territory.

The location of the customer and the legal address of the construction organization may vary with the location of the construction site. Building address may be in the jurisdiction of other judicial and expert institutions of the Ministry of justice, with its database, with specific information tailored to the local peculiarities. Therefore, the court shall designate another court at the location of the construction object to assign the examination of specific EMS or specific experts that provided h. 2. article 79 of the code of civil procedure.

Perhaps in absentia proceedings examination in absentia, according to article 234 of the CPC. Then the court examines the case in a General manner: examine evidence, conclusions and explanations of experts, consultations of specialists.

Court rulings, except for judicial decisions of the Supreme Court of the Russian Federation, may be appealed (article 377 code of civil procedure) the court of cassation by persons involved in the case, and other persons if their rights and legitimate interests are violated by judicial decisions. The reasons may serve as an illegal decision of a court (article 378 of the code of civil procedure), as well as knowingly false expert opinion (section 2, part 3.St.392 CCP). If the court cancels the decision on these grounds, the new proceeding will require the appointment of new, as a rule, Commission examination.

The court decides on the appointment of expertise in the deliberation room (article 80 of the code of civil procedure, article 224 of the CPC).

In the arbitration process, as civil examination conducted on behalf of the court to ensure the necessary evidence. According to the article 72 of the APC interested in the case a person may petition the court for providing the necessary evidence (article 72 of the APC). For STA it matters when there are hidden construction defects and deficiencies, for example, in the study of foundations, floor slabs, utilities, low-voltage systems of buildings, 
etc. Only building technical expertise in specified court time will establish some of the results of the hidden works which are the subject of litigation.

A controversial issue today is the question of the timing of the examination, which, in accordance with part 4 of article 82 APK single-handedly resolved by the court without consulting with an expert. But only competent in building a person can really assess the timing of the necessary studies to collect the necessary evidence for the court.In reality, research real estate required many design, technical and regulatory documents that have to inquire various instances, and in their preparation and analysis will take some time. Is positive review this part of the article. 82 APK followed, on the contrary, stricter: in case of delay in execution time of examination. According entered into force the Federal law of the Russian Federation from June, 28th, 2009 n 124-FZ (articles 4,5 FZ) "About modification of separate legislative acts of the Russian Federation" in article 55 APK added part 6 providing for judicial penalties for non-compliance with the deadlines of the examination in accordance with Chapter 11 APK. This provision applies to civil proceedings (articles 80, 85 of the CCP). This formal approach can lead to the poor result, that is, not a full expert opinion, since the expert (experts) is restricted to a rigid timetable and penalty threats.

By analogy with the CCP the arbitral Tribunal, if necessary, appoint additional, repeated (article 87 APC), complex (p. 85 APK) and Commission expert examination (article 84 of the APK).

Expertise may be appointed to administrative procedure in case of unclear interpretation of departmental rules and regulations for specific situations, having a technical-legal nature and regulatory processes of design, construction, overhaul, refurbishment, special works, demolition and other activities on construction projects. A distinctive feature of the Code of administrative offences in part of the examination is the lack of provisions on appointment of additional, repeated, complex or Commission examination. In this case, resort to Federal law No. 73 on GSAD. Specific, that according to section 6 of article 25.9 of the administrative code a competent person is engaged as an expert force and is responsible for giving knowingly false conclusion under part 3 of article 25.9 of the administrative code of administrative responsibility.

Issues of improvement of the procedural legislation examined A. Y. Butyrin in his work "Theory and practice of judicial construction and technical expertise" [22]. Some changes have been made in procedural laws, the others are still being discussed. Scientists are encouraged to improve procedural law to introduce the concept of additional and repeated, Commission and complex expertise in article 26.4 of the administrative code, as in code of civil procedure and the APK these concepts are already in place. It is important from a legal point of view, to exclude provisions on compulsory assistance of a qualified and expert to the proceedings of an administrative offense under threat of administrative punishment (items 2, 5, article 25.8, p. 1, 6, article 25.9 of the administrative code).

Should support and suggestions A. Y. Butyrin about introduction of additions and clarifications to the procedural law of the AIC, GIC, of the administrative code and the Federal law on GSAD on the introduction of the concept of "expert examination" providing a self-conducting field surveys of the facility and the concept of "samples" (currently "samples for comparative research") [22]. On-site inspections of construction projects in practice are often. For obvious reasons, are held outside the courtroom, without the involvement of a judge. The lack of procedural regulation the concept of "expert examination" is often at the hearing weaken the position of the expert in critical arguments of opponents.

On-site inspections of construction projects in practice are often. For obvious reasons, are held outside the courtroom, without the involvement of a judge. The lack of procedural regulation the concept of "expert examination" is often at the hearing weaken the position of the expert in critical arguments of opponents. 
The concept of "samples for comparative research", as stated in article 9 of the Federal law on GSAD should be reduced to the concept of "samples" to expand the scope of activities, as in the production of SSTI samples of construction products are selected not only for comparative analysis, but also for other research, namely, diagnostic, and classification.

The leading role in the organization, STA belongs to the judicial authority, the judge, as the judge decides on the involvement of individuals with special building knowledge as a specialist Builder for participation in a court action either as a court expert for STA.

But even after engaging competent person as a specialist Builder or as a court expert, and the submission of the results of the examination, the court (judge) shall give a decision on the reliability of these data and the need to attract them to the case (clause 3 of article 86 of the code of civil procedure of the Russian Federation).

Unacceptable, replace the definition of the court other documents, including a checklist designed for the expert Builder. At the $\mathrm{V}$ International scientific-practical conference "Theory and practice of forensic examination in modern conditions" held in Moscow on 2223 January 2015, the participants of the conference Chubina E. A., speaking on the overview of court practice related to echoes article 16 of the decree of the Plenum of the RF from 08.10.2012 article 58, drew attention to the inadmissibility of substitution of the expert opinion, made in accordance with the requirements of procedural legislation, other materials, the status of which is limited to written evidence [19].

\section{Conclusions}

In this article the analysis of existing procedural conflicts during the judicial construction and technical expertise. Conflict resolution is unification of legal regulation of forensic activities in the Russian Federation, the need for a common legal definition judicial-expert activity in the legal democratic state and civil society. The inclusion of the legal grounds for the appointment of additional and repeated expert examination due to the emergence of new issues in all procedural codes with the same wording. To define additional, repeated, and Commission a comprehensive examination in the administrative procedure act. The definition of "expert inspection" in procedural law. Discussed issues of cooperation between the court and experts in terms of expertise .

Invited to the exclusion of the rules on mandatory participation of a specialist and expert in administrative proceedings under threat of administrative punishment.

In recent years, in the course of numerous discussions, adjustments were made on the issue of legal regulation of information security procedures and increasing the availability of information on the consideration and resolution of civil cases. New Federal laws dated December 22, 2008 № 262-FZ "On providing access to information on courts 'activities in Russia", made corresponding changes in sectoral legislation - the Federal law dated 27 July 2010 No. 228-FZ "On amendments to the Arbitration procedural code of the Russian Federation". The Federal law of 23.06.2016 N 220-FZ "On amendments to certain legislative acts of the Russian Federation regarding the use of electronic documents in activity of judicial authorities" was amended to the Arbitration procedure code and Civil procedure code, concerning the availability receiving and placing information on the official website of the court in is information-a telecommunication network "the Internet"[23]. In Arbitration procedural code was amended in articles 4, 15, 41, 75,92, 99, $122,125,129,135,169,176,177,184,186,229.5,265.1,283,288.1,291.6,308.4$. To the civil procedure code was supplemented with article 3, 13, 35, 71, 113, 131, 139, 199, 214, 224, 227, 381, 391.5.

Despite the existence of the positive changes that are made in the procedural law, has yet to resolve some of the conflicts in the legal sphere of knowledge. As said earlier: the 
main task of improvement of legislation on judicial-expert activity in the Russian Federation is its unification regardless of the type of production, as well as the necessary changes and additions to the procedural legislation related to the appointment, organization and production expertise, evaluation of expert opinions.

The past in October 2015 years Kazakhstan international legal forum "development of forensic expertise in the context of the Eurasian Economic Union» brought together participants of the modern court proceedings in an effort to transition to a qualitatively new level of forensic technology.Currently, the ways of upgrading expertise in Eurasia, such as standardization, accreditation, certification, validation and inter-laboratory proficiency testing. One of the priority directions for development of the Eurasian Economic Union is the coordination of scientific-methodical work, improving the provision of information, the development of new hi-tech investigation techniques [24, 25].

\section{References}

1. I.P. Pryadko, PGS, 12, 60-63 (2013).

2. Newspaper Building 1 (10376) 11 Jan (2016)

3. S. Drobyshevsky, M. Kazakova, Journal "Russian Economic developments" 12, 46-50 (2015)

4. Pryadko I.P. Int. J. of Applied Engineering Research, 21, 42147-42152 (2015)

5. URL: www//http://mke.mos.ru.(2016)

6. Ch. Koliba, M. DeMenno, N. Brune, A. Zia. Lessons from a statewide public-private partnership Original Research Article Energy Policy, 74, 243-252 (2014)

7. URL: http://spb.rbcplus.ru/news/57614b447a8aa97de11f8aa7(2016)

8. R. Nadafianshahamabadi, M. Tayarani, G. M. Rowang. Sustainable Cities and Society, 28, 67-75 (2017)

9. A. Tennøy, L. Hansson, E. Lissandrello, P. Næss. Progress in Planning, 109, 1-32 (2016)

10. Ishkov A.D., Mishlanova M.Y., Grabovyi K.P. Int. J. of Applied Engineering Research, 11(3) 1676-1679 ( 2016)

11. A. Yu. Butyrin, I. A. Danilkin, Forensic examination.3 (47) 63-71 ( 2016)

12. Yu. N. Andreev, Judicial protection of housing rights of citizens (Legal center Press, $\mathrm{SPb}, 2013)$

13. A. Kozierkiewicz-Hetmańska. Information Fusion, 34, 80-86 ( 2017)

14. B. Wynne, M. Lynch. International Encyclopedia of the Social \& Behavioral Sciences (Second Edition), 206-211 (2015)

15. N. Dew, S. Read, S. D. Sarasvathy, R. Wiltbank. Journal of Business Venturing Insights, 4, 30-37 (2015)

16. R. Miller, B. E. Turvey. Judicial Ethics. Ethical Justice. 345-375 (2013)

17. R. Prince . Geoforum, 41, 875-884 (2010)

18. E. Herowati, U. Ciptomulyono, J. Parung, Fuzzy Sets and Systems, In Press, Corrected Proof, (2016)

19. Press release of the V International scientific-practical conference "Theory and practice of forensic examination in modern conditions", Moscow, January 22-23, 2015.(2015) 
20. F. G. Aminev, II International Scientific-Practical Conference, May 21-22, Volgograd : VA MVD Russian. 18 (2014),

21. Yu. K. Orlov, Journal "Forensic investigation" 3 (47), 10-18 (2016)

22. A. Y. Butyrin, Theory and practice of judicial construction and technical expertise. (Gorodets, Moscow, 2006)

23. Russian Federal law of 23.06.2016 N 220-FZ (2016)

24. S.V. Kolobova, MATEC 73, (2016)

25. A.I. Usov, Law and State no. 1 (70), 48-52 (2016) 